\title{
MENUMBUHKAN KETERAMPILAN WIRAUSAHA REMAJA MELALUI PELATIHAN ENGOLAHAN MAKANAN BERBAHAN DASAR PISANG DI PANTI ASUHAN AL-FAJAR PEKANBARU
}

\author{
Hammam Zaki*, Wan Laura Hardilawati, Hichmaed Tachta Hinggo S, \\ Siti Masitoh Sinaga \\ Program Studi Manajemen, Fakultas Ekonomi dan Bisnis \\ Universitas Muhammadiyah Riau \\ email: hammamzaki@umri.ac.id
}

\begin{abstract}
The purpose of this dedication is to provide supplies for the children of Al-Fajar orphanage in order to have the skills, knowledge and attitude in entering the selfemployment world as one of the efforts in order to foster life skills for children who live in orphanage by providing education non-formal in the field of entrepreneurship. The training is not in the form of giving materials but through direct practice to the orphanage children who in fact are high school students to high school level. The practice is in the form of making banana based foods with different creations and innovations. The outcome target of this devotion program is to increase the awareness of lecturers to the community, but it can be a motivation and inspiration for the orphanage children when they start. With good entrepreneurial knowledge, it is expected to be able to cultivate a mature self-reliance, so that the cost of living and education costs can run smoothly and can help ease the burden of the institution, so they need to be empowered to improve the quality of life.
\end{abstract}

Keyword: Entrepreneur,creativity,innovation

\begin{abstract}
Abstrak
Tujuan dari pengabdian ini adalah memberikan bekal bagi anak-anak panti asuhan Al-Fajar agar memiliki keterampilan, pengetahuan dan sikap dalam memasuki dunia wirausaha yang mandiri sebagai salah satu upaya dalam rangka menumbuhkan kecakapan hidup bagi anak-anak yang tinggal di panti asuhan dengan memberikan pendidikan non formal dalam bidang kewirausahaan. Pelatihan yang dilakukan tidak berupa pemberian materi tetapi melalui praktek langsung kepada anak-anak panti asuhan yang notabene adalah siswa siswi sekolah menengah pertama sampai dengan sekolah menengah tingkat atas. Praktek yang dilakukan berupa pembuatan makanan berbahan dasar pisang dengan kreasi dan inovasi yang berbeda. Target luaran dari program pengabdian ini adalah meningkatkan kepedulian dosen kepada masyarakat, selain itu dapat menjadi motivasi dan inspirasi bagi anak-anak panti asuhan saat nanti memulai berwirausaha. Dengan pengetahuan kewirausahaan yang mumpuni, diharapkan akan mampu menumbuhkan sikap kemandirian yang matang, agar biaya hidup dan biaya pendidikan dapat berjalan lancar serta dapat membantu meringankan beban panti, maka mereka perlu diberdayakan untuk perbaikan kualitas hidupnya.
\end{abstract}

Kata kunci: Wirausaha, Kreativitas, Inovasi. 


\section{PENDAHULUAN}

Fenomena di Indonesia mayoritas lulusan SLTA $(61,88 \%)$ lebih memilih menjadi karyawan daripada menjadi wirausaha. Sejalan dengan hal tersebut, maka diperlukan adanya pelatihan kewirausahaan sejak dini kepada kelompok masyarakat. Target kegiatan pengabdian kepada masyarakat ini adalah menumbuhkan keterampilan wirausaha baru dari kalangan anak-anak pantiasuhan. Pelatihan kewirausahaan bagi anak panti asuhan ditujukan agar mereka bisa hidup mandiri setelah lepas dari yayasan. Anak-anak dituntut untuk memiliki kemadirian finansial saat usia mereka menginjak 18 tahun (lulus SMA). Namun demikian untuk mencapai kemandirian finansial bukan kondisi yang dapat diciptakan dalam waktu singkat.Kemandirian tersebut perlu ditumbuhkembangkan dari waktu ke waktu.

Perlunya menumbuhkan jiwa kewirausahaan dari sejak dini dikarenakan pada usia yang masih muda semangat yang dimiliki masih besar, daya kreasi dan inovasi sangat tinggi begitu juga dengan energi yang dimiliki. Guna mendukung hal tersebut, para wirausahawan muda ini harus dibekali dengan keterampilan-keterampilan guna mengembangkan dan membentuk karakteristik wirausahawan muda yang tangguh dan siap berkompetisi sekaligus bersaing dalam bisnis yang sama.

Keterampilan usaha yang dimiliki oleh anak-anak panti asuhan juga masih tergolong sangat terbatas, karena belum pernah mendapatkan pendampingan dari pihak-pihak yang berkompeten dalam bidang kewirausahaan. Padahal jika dilihat dari usia mereka yang tergolong produktif, mereka memiliki potensi untuk berkembang dalam kegiatan kewirausahaan yang kreatif sesuai jiwa muda anak-anak panti asuhan. Kendala lain yang dihadapi Panti Asuhan pada umumnya adalah rendahnya motivasi wirausaha.

Dalam hal ini kami membidik remaja putra dan putri Panti Asuhan Alfajar yang berlokasi di Muara Fajar Pekanbaru tingkat SMP dan SMA. Alasan kami memilih Panti Asuhan Alfajar ini dikarenakan remaja putra dan putri di panti asuhan ini belum mendapatkan materi kewirausahaan yang akan membantu mereka menghadapi persaingan yang semakin ketat dalam bidang pekerjaan. Berdasarkan hasil wawancara yang dilakukan terhadap anak asuh panti, disimpulkan bahwa sebagian besar mereka memiliki kecerdasan yang sama dengan remaja-remaja lainnya yang memiliki hidup sangat layak, namun untuk kemandirian, kematangan emosi dan kematangan sosial dirasakan masih sangat kurang.

Hasil identifikasi menunjukkan ada permasalahan yang dihadapi dan harus dipecahkan oleh Tim pelaksana jika dilihat dari berbagai sudut pandang yang relevan, yaitu pertama adalah ketrampilan kewirausahaan yang dimiliki masih terbatas. Kedua, belum memiliki target dan sasaran usaha apa yang akan dibuat. Ketiga, belum memiliki keahlian dalam promosi dan pemasaran. Salah satu upaya kami dalam membantu menyelesaikan masalah-masalah yang dihadapi yaitu dengan cara menumbuhkan keterampilan wirausaha di kalangan remaja panti asuhan al-fajar berupa pelatihan keterampilan pengolahan makanan berbahan dasar pisang, karena kami lihat usaha ini sedang memiliki prospek yang cukup baik, banyak konsumennya, cukup mudah pembuatannya, dan modal yang diperlukan tidak terlalu besar.

Dengan mendapatkan pelatihan keterampilan tersebut diharapkan dapat menjadi sarana bagi penghuni panti untuk mengasah soft skill dan 
termotivasi untuk berwirausaha . Pelatihan yang diajarkan tidak hanya sekedar untuk mengembangkan ketrampilan maupun mengasah soft skill saja, akan tetapi dapat digunakan untuk menambah uang saku, dan mereka akan menjadi lebih mandiri secara finansial.

Berdasarkan uraian diatas, maka perlu dilakukan pelatihan tentang bagaimana menumbuhkan keterampilan wirausaha melalui pengolahan makanan berbahan dasar pisang terhadap remaja di panti asuhan al-fajar Pekanbaru. Kegiatan ini memiliki tujuan untuk memberi pelatihan bagaimana menumbuhkan keterampilan wirausaha melalui pengolahan makanan berbahan dasar pisang terhadap remaja di panti asuhan al-fajar Pekanbaru.

Dari penyuluhan ini diharapkan dapat memberikan manfaat Bagi remaja putra-putri panti asuhan al-fajar memiliki bekal keterampilan wirausaha sehingga di masa depan mampu menjalani kehidupan secara mandiri serta menumbuhkan kreatifitas dan inovasi dalam hal berwirausaha.

\section{METODE PENGABDIAN}

Pengabdian ini dilaksanakan di Panti Asuhan Al-Fajar Pekanbaru. Pelaksanaan pengabdian ini melibatkan beberapa pihak, diantaranya kepala pengasuh beserta pengasuh lainnya dan anak-anak panti asuhan usia remaja yang sekaligus merupakan peserta pelatihan. Metode kegiatan pengabdian masyarakat ini berupa pemberian pelatihan melalui praktek keterampilan, diskusi dan Tanya jawab.

Pelaksanaan pengabdian ini dilakukan dengan tiga tahap. Tahap awal pengabdian ini yaitu tahapan persiapan. Pada tahap ini tim pelaksana kegiatan melakukan konsultasi dengan anggota yang lain. Kemudian melakukan survey dan observasi terhadap Panti Asuhan sasaran dan melakukan koordinasi kepada pihak yang bersangkutan.
Tahap kedua yaitu tahap pelaksanaan kegiatan pengabdian, Pada tahapan ini tim terlebih dahulu melakukan silaturrahmi sebelum pelatihan diselenggrakan, kemudian berbincang dengan para pengasuh seputar kondisi anak-anak panti khususnya yang berkaitan dengan pendidikan kewirausahaan. Setelah itu, tim langsung memberikan praktik keterampilan wirausaha. Setiap peserta pengabdian mendengarkan paparan dari narasumber sekaligus ikut terlibat langsung dalam proses pembuatan. Selama proses pelatihan berlangsung, peserta diberi kesempatan untuk bertanya secara langsung bersamaan setelah itu tim juga memberikan pengalaman bagaimana memulai usaha dan mengasah kreativitas dan inovasi dalam mengelola usaha.

Tahap terakhir yaitu tahap evaluasi. Rencana evaluasi pelaksanaan dengan mengadakan pengamatan langsung di lapangan terhadap peserta pelatihan. Evaluasi yang dilakukan dengan mengecek minat anak asuh dalam berwirausaha, mengecek kondisi usaha yaitu keadaan usaha, sudah berjalan atau belum berjalan, prestasi yang dicapai terkait dengan omset, kondisi keuangan, jangkauan pasar, dan jumlah variasi produk.

\section{HASIL DAN PEMBAHASAN}

Pengabdian kepada masyarakat yang dilaksanakan di Panti Asuhan AlFajar, Jl. Yos sudarso KM. 15, Muara Fajar, Kecamatan Rumai, Kota Pekanbaru. Kegiatan ini dilaksanakan sesuai dengan jadwal yang telah ditetapkan dan di sepakati bersama dengan pihak Panti Asuhan Al-Fajar. Langkah awal yang dilakukan yaitu persiapan dan permohonan izin kepada pihak Panti Asuhan yang menjadi tujuan pengabdian masyarakat, selanjutnya dilakukan pencarian informasi jumlah peserta dan kegiatan 
peserta sebelum di adakan pelatihan. Setelah waktu pelaksanaan di sepakati, tim dari dosen Prodi Manajemen menyusun jadwal pelaksanaan dan membuat kesepakatan dengan pihak Panti Asuhan Al-Fajar mengenai jadwal pelaksanaan.

Kegiatan pelatihan ini dilaksanakan dalam rangka melaksanakan Catur Dharma Perguruan Tinggi Muhammadiyah, yang salah satunya adalah pengabdian kepada masyarakat. Pelatihan ini diberikan untuk anak-anak panti asuhan yang menginjak usia remaja, adapun bentuk pelatihan yang dilakukan adalah keterampilan wirausaha remaja melalui pelatihan pengolahan makanan berbahan dasar pisang.. Pelatihan ini diberikan untuk menambah keterampilan dan pengetahuan bagi anak-anak panti asuhan karena keterampilan yang dimiliki oleh anak-anak panti asuhan juga masih sangat terbatas.

Dalam proses pelaksanaan pelatihan tahapan pertama yang dilakukan dimulai dengan tahapan persiapan, di mana tim pelaksana melakukan briefing untuk penyiapan bahan-bahan yang dibutuhkan pada saat pelatihan, membagi tugas masing-masing pembicara, menyiapkan para peserta pelatihan, menyiapkan materi pelatihan yang berhubungan dengan pembimbingan dan praktik berwirausaha.

Kegiatan dilaksanakan sesuai dengan waktu yang telah di sepakati yaitu pada tanggal 03 Maret 2018 bertempat di ruang tamu panti asuhan. Tahapan pelaksaaan kegiatan dimulai dengan bersilaturrahmi dan pelatihan keterampilan pengolahan makanan berbahan dasar pisang. Tahapan pelaksanan selanjutnya yaitu diskusi dan sharing experience bersama anak-anak panti asuhan.

Pelatihan diberikan kepada seluruh peserta berupa cara membuat produk makanan yang menarik dan memiliki daya jual di pasaran. Saat pelatihan berlangsung tim juga menyelipkan sedikit penjelasan bagaimana membuat produk yang kreatif dan inovatif serta alasan kenapa produk ini yang dipilih dalam praktik pelatihan. Peserta juga di berikan kesempatan untuk bertanya seputar produk maupun yang berkaitan dengan pemasaran produk.

Evaluasi pada tahap pertama telah sesuai dengan indikator dan rancangan evaluasi diperoleh data sebagai berikut:

1. Jumlah peserta yang hadir sebanyak 22 orang sehingga tingkat kehadiran mencapai $100 \%$.

2. Peserta sangat terlihat antusias selama mengikuti kegiatan hingga pelatihan selesai

3. Setiap peserta aktif mengutarakan pertanyaan dan diskusi dalam pemecahan masalah dan kendala yang dialami pada saat memulai dan menjalankan usaha.

4. Setelah dilakukan pelatihan diharapkan para remaja Panti Asuhan Al-Fajar Pekanbaru memiliki karakteristik wirausahawan muda yang tangguh dan siap berkompetisi sekaligus bersaing dalam bisnis yang sama.

Secara umum evaluasi yang dilakukan terlaksana dengan baik, dan peserta dan pengasuh panti asuhan berharap kegiatan ini terus berkelanjutan kedepannya dengan variasi produk yang berbeda dan lebih inovatif.

\section{SIMPULAN}

Pelatihan yang dilakukan pada akhirnya mampu menumbuhkan intensi mereka untuk berwirausaha karena proses kegiatan pembuatan makanan berbahan dasar pisang ini mudah diingat dan mudah dilakukan sehingga setelah kegiatan pelatihan ini berakhir peserta mampu membuat produk itu sendiri dan 
bersedia menjual produk itu sebagai usaha dalam menumbuhkan jiwa wirausaha.

Peserta merespon kegiatan pelatihan ini dengan baik. Mereka merasa senang dan nyaman selama mengikuti kegiatan pelatihan. Mereka juga mampu mengikuti setiap arahan dari pemateri dan sangat antusias mengikuti kegiatan pelatihan ini mulai dari awal hingga akhir pelatihan, hal ini dikarenakan sangat jarang mereka mendapatkan kegiatan dalam bentuk praktek yang dapat menambah ketrampilan dan melatih kemandirian melalui pelatihan.

\section{UCAPAN TERIMAKASIH}

Ucapan terimakasih kami ucapkan kepada Lembaga Penelitian dan Pengabdian Masyarakat (LPPM) atas bimbingan dan pemberian bantuan dana pengabdian kepada masyarakat. Serta uacapan terimakasih kami ucapkan kepada pihak panti asuhan Al-Fajar yang telah mendukung dan menyediakan fasilitas agar terselenggaranya kegiatan ini serta rekan dosen dan mahasiswa yang terlibat langsung mendukung kelancaran kegiatan pengabdian ini.

\section{DAFTAR PUSTAKA}
[1] Buchari
Alma.
(2016).

Kewirausahaan. Bandung: Alfabeta. Anggota Ikatan Penerbitan Indonesia.

[2] Buchari Alma. (2016). Kewirausahaan. Bandung: Alfabeta. Anggota Ikatan Penerbitan Indonesia.

[3] Gerry, sholeh. (2017),). Pemberdayaan remaja panti asuhan melalui pembuatan nugget guna menumbuhkan minat berwirausaha. ABDIPAMAS, 1(1), 118-127.

[4] Jannah, Kusniasih Miftakhul. 2014. Pertumbuhan Wirausaha Indonesia Masih Terbatas. Online. (m.okezone.com/read/2014/11/21/3 20/1069038/pertumbuhanwirausaha-indonesia-masihterbatas).

[5] Kasmir. (2017). Kewirausahaan. Jakarta : Penerbit Rajawali Pers

[6] Kottler Philip.G Amstrong. (2012). Manajemen Pemasaran.Edisi 13, jilid 1. Jakarta. Penerbit Erlangga.

[7] LP2M. (2017). Pedoman Penulisan Penelitian dan Pengabdian pada Masyarakat Universitas Muhammadiyah Riau. 